\title{
Physical, physiochemical and electrochemical responses of 'Galaxy' apples to mild bruising
}

\author{
M. Ergun \\ Department of Horticulture, Bingol University, Bingol, Turkey
}

\begin{abstract}
Summary
Minor mechanical injuries such as shocks, vibrations, compressions cause tissue damages and eventually quality losses of fruits. Bruising one of type of the minor mechanical injuries is usually neglected and might result serious postharvest losses. The study was set out to evaluate physical, physiochemical and electrochemical quality parameters of 'Galaxy' apples bruised with a 50- or $70-\mathrm{N}$ compressive force followed by storage at $15^{\circ} \mathrm{C}$ for 20 days. The degree of bruising on fruit skin and in mesocarp tissue was subjectively and instrumentally measured. The 70- $\mathrm{N}$ force caused more bruising than the $50-\mathrm{N}$ force, as expected. Darkening and reddening were found to be the most significant coloring symptom of bruised tissues. Showing a steady rate over time, neither weight nor firmness loss was affected by bruising. Bruising also did not have a significant effect on soluble solids, titratable acidity or vitamin $C$ contents, all of which slightly decreased in the course of the storage. Expressing a decline with storage duration, electrochemical parameters redox potential, $\mathrm{pH}$, P-value and resistivity quantified by Bioelectric Vincent method were not significantly affected by bruising as well. The rate of decline in P-value and resistivity of apples was however sharper than in redox potential and $\mathrm{pH}$, irrespective of bruising treatment. The Bioelectric Vincent method was found to be insufficient to detect mild bruising on 'Galaxy' apples. Instrumental colorimeter, however, detected the bruising very effectively.
\end{abstract}

\section{Keywords}

apple fruit quality, Bioelectric Vincent method, P-value, redox potential, resistivity

\section{Introduction}

Minor mechanical injuries on fruits have become a very important problem to detect/overcome with the rising use of mechanical equipment at harvest and after harvest (harvesting, packing, transporting, etc.). For apples, similar to many fruits, bruising is one of the main mechanical injuries during or after harvest, owing to various mechanical strains such as shocks, vibrations, compressions, all of which cause tissue damage and eventually quality losses. Minor bruising, usually neglected, could be a very serious problem with its consequent fungal infections (Zeebroeck et al., 2007). Thus, if bruising could be avoided, there would be fewer losses of fruit and eventually less use of chemicals against pathogens (Knee and Miller, 2002). Due to bruising, the postharvest

\section{Significance of this study}

What is already known on this subject?

- "Bioelectric Vincent method" is a novel fruit quality assessment method.

\section{What are the new findings?}

- Instrumental calorimetry of fruit flesh detects minor bruising very effectively in "Galaxy" apple.

What is the expected impact on horticulture?

- Bioelectric Vincent method was however found to be insufficient to detect minor bruising on 'Galaxy' apples.

losses for apples, although most commonly in the range of $10-25 \%$, could be as high as $50 \%$ (Studman, 1997). Therefore, it is very crucial to detect and prevent the harvest or postharvest procedures that may lead to minor bruising on skin or in flesh. To be successful, bruised fruit lot must be detected and separated from healthy lots. Bioelectric Vincent method would be a simple way to detect whether a fruit has minor bruising that cannot be spotted with naked eyes.

Bioelectric Vincent method has been tested on fruit quality by German and Austrian researchers for three decades (Hoffman, 1991; Keppel, 1998; Meltsch et al., 2005). French hydrologist Jean-Claude Vincent founded this method in 1935 (Kappert and Meltsch, 2007). Three basic factors pH, redox potential ( $\mathrm{rH}$ in $\mathrm{mV}$ ) and resistivity ( $\mathrm{R}$ in $\Omega$ ) make up the basis of the method, which translated into P-value an electrochemical parameter of product quality (Kappert and Meltsch, 2007). P-value has been usually used as one of the quality parameters for degrading products. Today, however, P-value is being tested as an integrative method of fruit quality assessments. According to Bioelectric Vincent method, better product quality or recovered products are attained by a low redox potential and P-value but a higher resistivity (Wolf and Rey, 1997). The method has been tested and found valuable for few fruits and vegetables including apples (Hoffmann, 1991; Keppel, 1998), oranges (Hoffmann, 1991), strawberries (Weissinger et al., 2008), plums (Ergun and Jezik, 2011), peaches (Ergun, 2012), grapes (Kok and Bal, 2017), pumpkins (Paulauskiene et al., 2006), carrots (Velimirov, 2004, 2005; Gajewski et al., 2007) and tomatoes (Akay and Kara 2006; Kaçiu et al., 2010).

The study was set out to determine whether mild bruising on 'Galaxy' apple fruit can be detected by Bioelectric Vincent method as opposed to well-known classical physical and physiochemical quality indices. 


\section{Materials and methods}

\section{Plant material and compressive bruising treatment}

Apples (Prunus domestica 'Galaxy') were harvested from 9-year old trees at commercial maturity stage according to fruit size and color from the experimental orchard of the University of Natural Resources and Life Sciences in Vienna (latitude: $48^{\circ} 17^{\prime} 9^{\prime \prime} \mathrm{N}$; longitude: $16^{\circ} 25^{\prime} 31^{\prime \prime} \mathrm{E}$; elevation approximately $200 \mathrm{~m}$ ). Fruits of uniform size and color, free from physical defects and diseases were chosen, and at harvest time the fruits showed the following parameters: flesh firmness, $100.07 \mathrm{~N}$; soluble solids concentration, $14.69 \%$; and titratable acidity, $0.38 \%$. More than 300 fruits were harvested and transported to the postharvest laboratory of the Institute where they were randomly divided into three groups having at least 100 fruits. Fruits from the first group were bruised using Mecmesin Microprocessor Force Gauge (M 1000E, Henko (S) Pte Ltd., Singapore) by a 50-N force on the equatorial zone, and the second group by a $70-\mathrm{N}$ force. Fruits from the third group were left non-treated as control.

Causing no puncture on fruit skin, the probe tip was convex and had $1 \mathrm{~cm}$ diameter. The bruised area was circled with black indelible ink; a similar circle was marked on the control fruit skin as well. The fruits were laid in plastic trays (10 fruits per tray/treatment) in commercial cardboard boxes (29.5 $\mathrm{cm}$ wide by $50.00 \mathrm{~cm}$ long by $10.0 \mathrm{~cm}$ high; one tray per box) then stored at $15^{\circ} \mathrm{C}$ for 20 days.

\section{Firmness and weight loss}

Fruit firmness was assessed on the equatorial zone with avoiding the bruised area and the opposite site of the bruised area as well after removing fruit skin using the Microprocessor Force Gauge. The convex probe tip with $1 \mathrm{~cm}$ diameter was penetrated into fruit flesh $5 \mathrm{~mm}$ at top speed of $10 \mathrm{~mm} \mathrm{~s}^{-1}$, and the reading was recorded as Newton (N). Ten fruits per treatment were used to assess firmness and other measurements indicated below. To estimate weight loss ratios (\%), ten fruits were weighed every 5 days during storage, using a balance with an accuracy of $0.01 \mathrm{~g}$ (A and D FX-3000i, Japan).

\section{Instrumental color}

Fruit skin and flesh color (10 fruits per treatment) for bruised and non-bruised fruit on the circled areas was measured using a Minolta CR-100 colorimeter, calibrated with a white reference plate. Measurements were recorded using standard CIE L* $a^{*} b^{*}$ color space coordinates.

\section{Bruise rating and deformation}

Bruising was assessed in two ways sequentially; first with visual rating, and second by excision and direct measurement of the cross-section of the bruised tissue. The visual assessment was based on a 4-point scale with: 1, none; 2 , light brown bruise with no define edges; 3 , moderately dark brown bruise with a well-defined edge; 4 , dark brown tissue (Toivonen et al., 2007). Bruise diameter (length $\times$ width) and depth were quantified in bruised tissues after removing only the outer layer of the fruit skin using a razor blade.

\section{Soluble solids content, titratable acidity and vitamin C}

Apples were passed through a juicer (Moulinex, 733, France) and filtered through a Whatman No. 4 filter paper for the assessment of soluble solids content (SSC), titratable acidity (TA) and vitamin C content. SSC was measured by a digital refractometer (Atago, Palette, PR-100, Japan). TA was quantified by titration of $5 \mathrm{~mL}$ juice diluted with $25 \mathrm{~mL}$ distilled water to $\mathrm{pH} 8.2$ with $0.1 \mathrm{~N} \mathrm{NaOH}$ and expressed as percentage malic acid. An automatic titrator (Schott, TA 20 Plus, Germany) was employed for the titration. Vitamin C content was quantified by a digital reflectometer (Qflex 10, Merck, Germany) equipped with ascorbic acid test strips (Merckoquant Ascorbic Acid Test, Cat. No. 1.10023.001, Merck, Germany) and expressed as mg/L L(+)-Ascorbic acid.

\section{Electrochemical values}

Redox potential $(\mathrm{mV}), \mathrm{pH}, \mathrm{P}$-value $(\mu \mathrm{W})$ and resistivity $(\Omega)$ were quantified from the juice prepared for the previous physiochemical analysis by a digital electrochemical quality assessment device (BE-T-Analyse Prof. n. Vincent, MEDTronik, Germany) with processing through a software (Med-Tronik, Terrrainanalyse 2.2, Germany). Approximately $30 \mathrm{~mL}$ of fruit juice from an individual fruit in a $50-\mathrm{mL}$ beaker on a magnetic stirrer was employed to determine the aforementioned values.

\section{Treatment design and statistical analyses}

A total of 60 fruits per treatment were employed in the present study. There were 6 cardboard boxes per treatment in the cold room holding 10 fruits. One cardboard box was used for weight loss assessment, 4 boxes were used for the aforementioned analyses and assessments, and 1 box was kept as a precaution. Randomly selected cardboard boxes ( 1 box per treatment) were removed from the cold storage every $5 \mathrm{~d}$ for 4 removals. The cardboard boxes were arranged in a completely randomized design. Analysis of variance (ANOVA) of data was conducted using SAS (release 8.1, SAS Institute, Cary, NC, USA) and treatment means were compared by the LSD test $(P \leq 0.05)$.

\section{Results and discussion}

\section{Firmness and weight loss}

Both non-bruised and bruised fruits had extensive firmness loss during the period of storage (Figure 1). Firmness loss at the end of the storage was more than 2-folds for all treatments compared to initial values (day 0). Fruits bruised with $70 \mathrm{~N}$ had higher firmness loss than non-bruised fruits from day 15 through the end, indicating clearly that even minor bruising in 'Galaxy' apples can cause faster fruit softening. Apples lost weight over time at $15^{\circ} \mathrm{C}$ irrespective of bruising treatments (Figure 1), implying that minor bruising, without puncturing the skin, may not be a serious threat to extensive weight loss in 'Galaxy' apples.

\section{Instrumental color}

Both skin and flesh color as $\mathrm{L}^{*}, \mathrm{a}^{*}$ and $\mathrm{b}^{*}$ values were measured on the circled skin area or flesh under the circled skin area for both bruised and non-bruised fruits (Figure 2). Considering to control fruit skin values, chromatic $\mathrm{L}^{*}$ and $\mathrm{b}^{*}$ values increased while $\mathrm{a}^{*}$ values decreased during the course of storage. Both bruising treatments suppressed these increases in $L^{*}$ and $b^{*}$ values, and the decrease in $b^{*}$ values.

Assessed from the control fruit flesh values, chromatic $\mathrm{L}^{*}$ and $\mathrm{b}^{*}$ values very slightly increased while $\mathrm{a}^{*}$ values very slightly decreased as storage time passed. Similar to the fruit skin, bruising suppressed these diminutive increases in $\mathrm{L}^{*}$ and $\mathrm{b}^{*}$ values whereas causing chromatic $\mathrm{a}^{*}$ values to increase significantly over time.

At the end of the storage, both bruised skin and flesh 


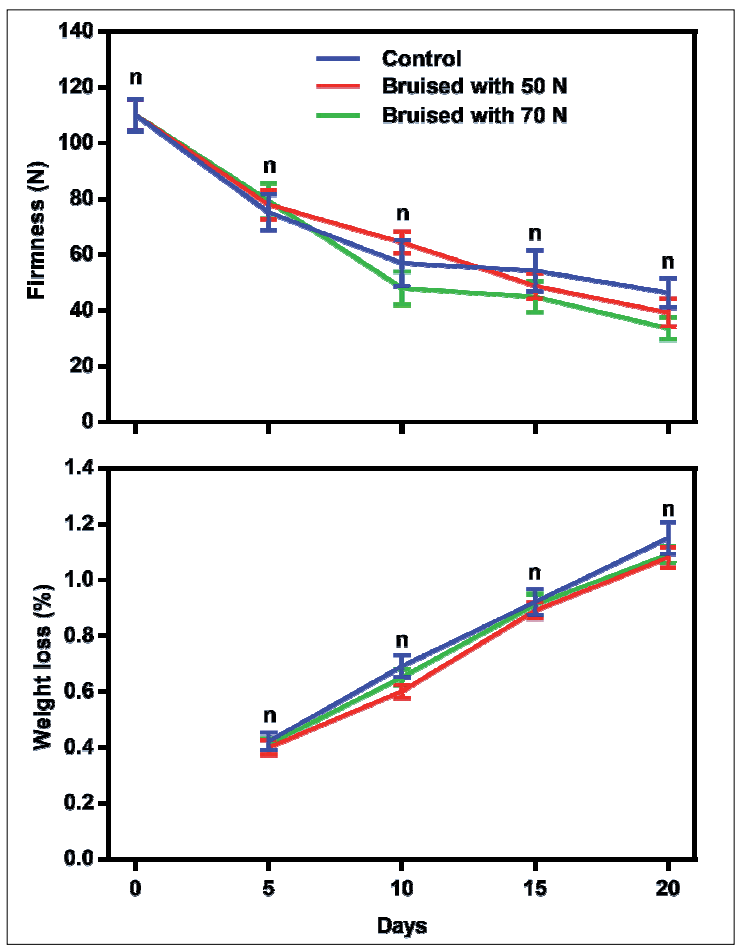

FigURE 1. Changes in firmness and weight loss of non-bruised and bruised 'Galaxy' apple fruits stored at $15^{\circ} \mathrm{C}$ for 20 days. Values are the mean \pm S.E. of 10 replicates. Means followed by the same letters on the same day are not significant different by LSD test at $P<0.05$. n: nonsignificant.

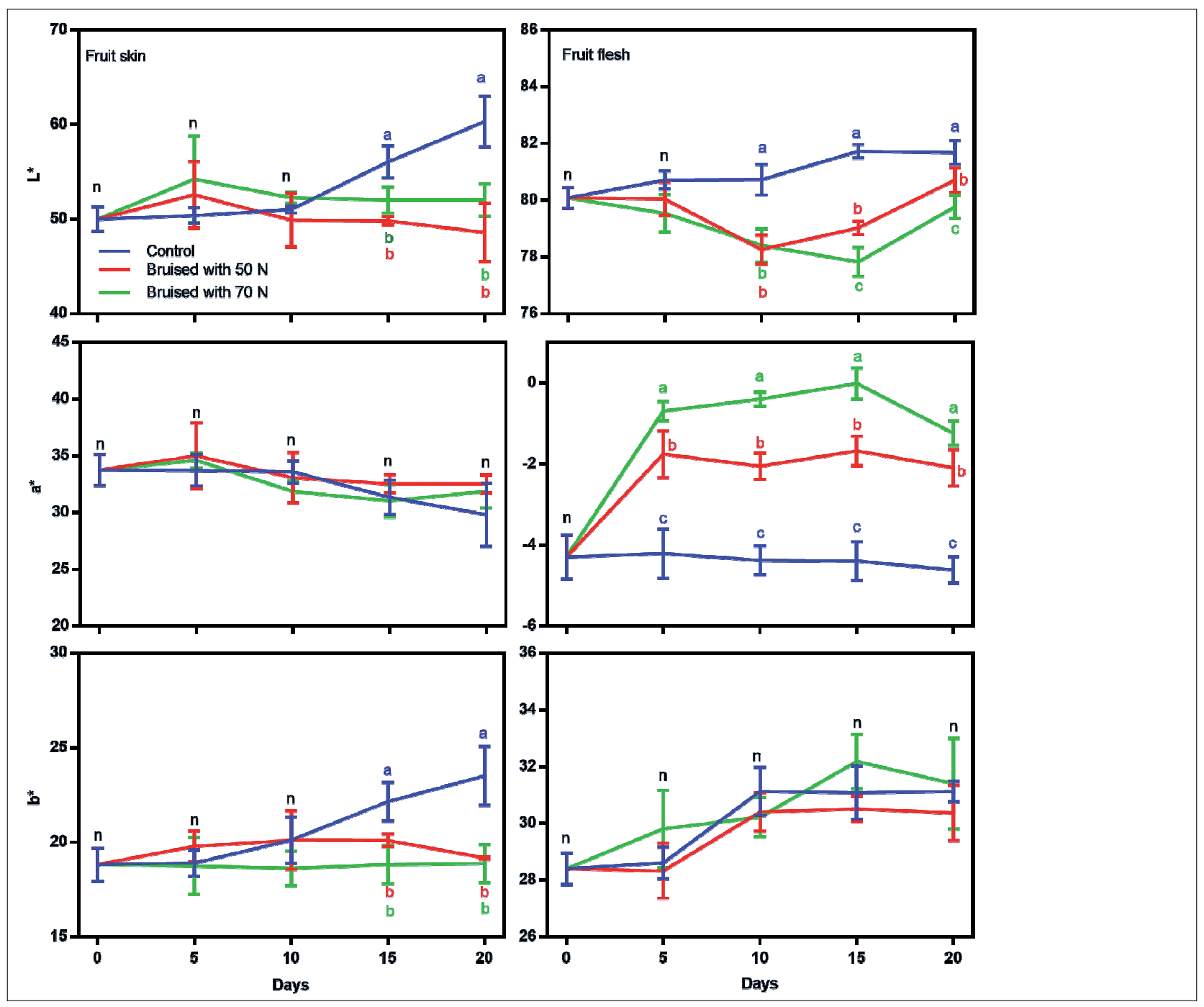

FIGURE 2. Changes in fruit skin and fruit flesh color of non-bruised and bruised 'Galaxy' apple fruits stored at $15^{\circ} \mathrm{C}$ for 20 days. Values are the mean \pm S.E. of 10 replicates. Means followed by the same letters on the same day are not significant different by LSD test at $P<0.05$. n: nonsignificant. 


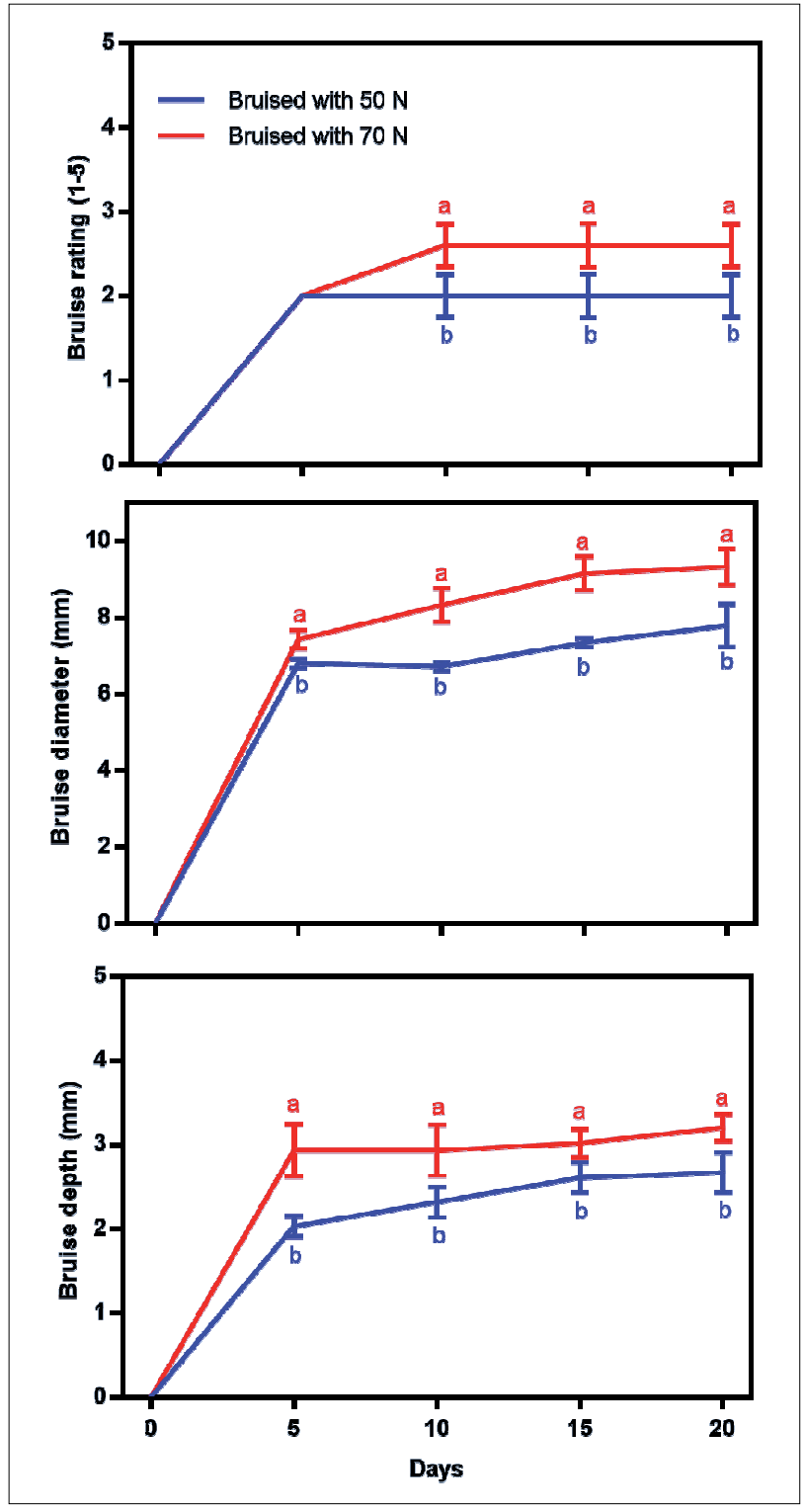

FIGURE 3. Changes in bruising rating, diameter and depth of non-bruised and bruised 'Galaxy' apple fruits stored at $15^{\circ} \mathrm{C}$ for 20 days. Values are the mean \pm S.E. of 10 replicates. Means followed by the same letters on the same day are not significant different by LSD test at $P<0.05$. n: nonsignificant. tissue showed lower $\mathrm{L}^{*}$ values compared to the non-bruised tissue in which $L^{*}$ color value naturally increasing, which corresponds to bruising may lead to tissue browning in 'Galaxy' apples by suppressing this natural increase in $\mathrm{L}^{*}$ values. Bruised tissue, especially in fruit flesh, had a higher $a^{*}$ value than non-bruised tissue, firmly stating that bruising causes more reddening in 'Galaxy' apples.

Demonstrating the intensity of yellow color, bruised skin showed higher $\mathrm{b}^{*}$ color values which are almost steady after harvest in 'Galaxy' apples. The suppression recorded for the increase in chromatic $\mathrm{L}^{*}$ and $\mathrm{b}^{*}$ values on bruised skin area, and in the increase in chromatic $\mathrm{L}^{*}$ and the in the slight decrease in bruised flesh area clearly indicates that even minor bruising can cause tissue discoloration on 'Galaxy' apples.

Phenolic compounds in apple cell vacuoles, brought in contact with catechol oxidase in the plastids as a consequence of the mechanical damage, lead to the formation of quinones polymerizing to the dark colored compounds (Knee and Miller, 2002), which may be the reason for darkening in bruised apple tissues in the present experiment.

\section{Bruising}

Bruise rating for both fruits compressed with $50-\mathrm{N}$ and with 70-N force ranged from 2 to 3 over time (Figure 3). Fruits bruised with $70 \mathrm{~N}$ had higher bruising values than fruits with bruised with $50 \mathrm{~N}$. Bruise diameters and depth was also higher for fruits bruised with $70 \mathrm{~N}$ (Figures 3 and 4). The data associated with bruising clearly indicate that bruised tissue in apples loses its natural color, and the loss intensifies as bruising forces increase. Both 50- and 70-N force were applied to apples to simulate compressive bruising which frequently occurs during harvesting.

Deformation due to bruising is effected by several factors but the cultivar is probably the well-documented factor so far in the literature (Zeebroeck et al., 2007). For example, Pasini et al. (2004) demonstrated that 'Fuji' apples are more susceptible to bruising than 'Gala', and Pang et al. (1996) found that 'Granny Smith' apples are more susceptible to bruising than 'Braeburn' apples. The discrepancies between cultivars are probably attributed to the differences in both fruit external and internal structures such as cell wall strength, cell wall elasticity, intercellular bonding, etc. (Zeebroeck et al., 2007).

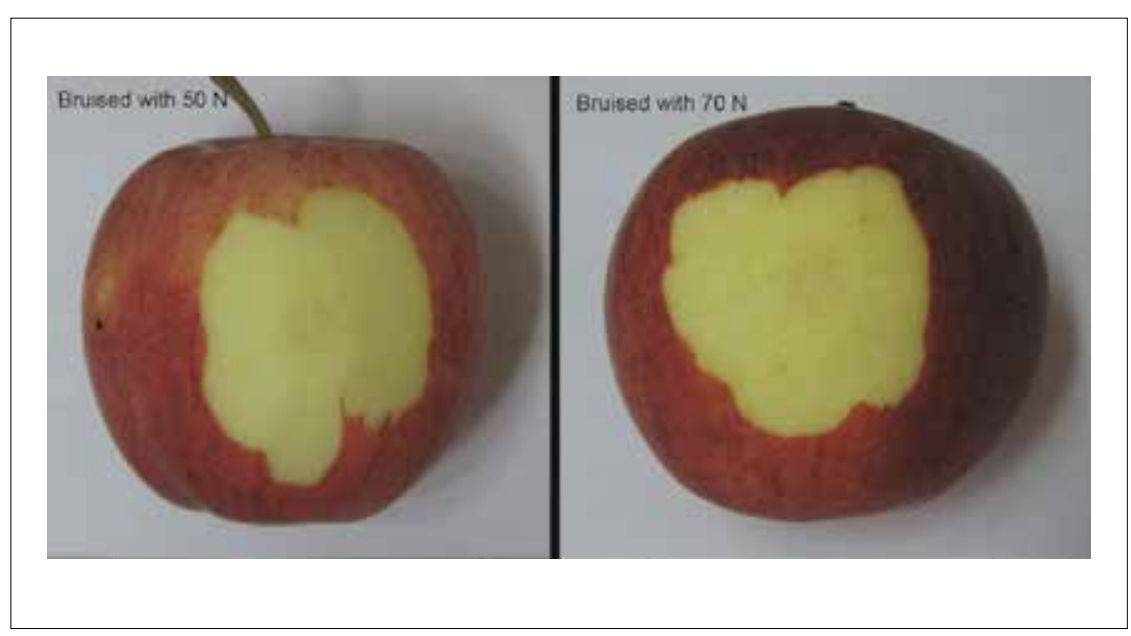

FiguRE 4. Mesocarp sections of bruised fruits at the last day of the experiments. 


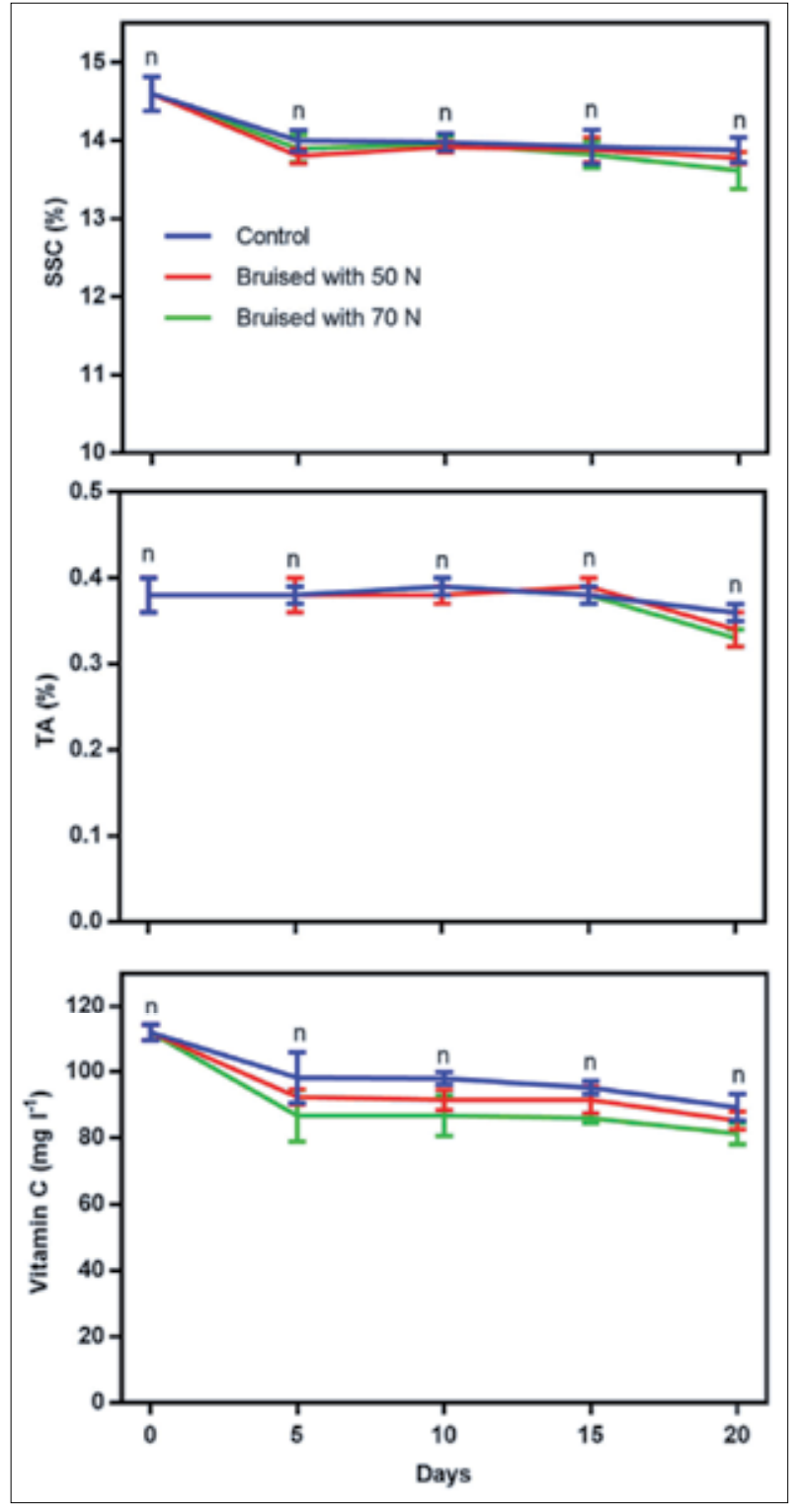

FIGURE 5. Changes in soluble solids content (SSC), titratable acidity (TA) and vitamin $C$ content of non-bruised and bruised 'Galaxy' apple fruits stored at $15^{\circ} \mathrm{C}$ for 20 days. Values are the mean \pm S.E. of 10 replicates. Means followed by the same letters on the same day are not significant different by LSD test at $P<0.05$. n: nonsignificant.

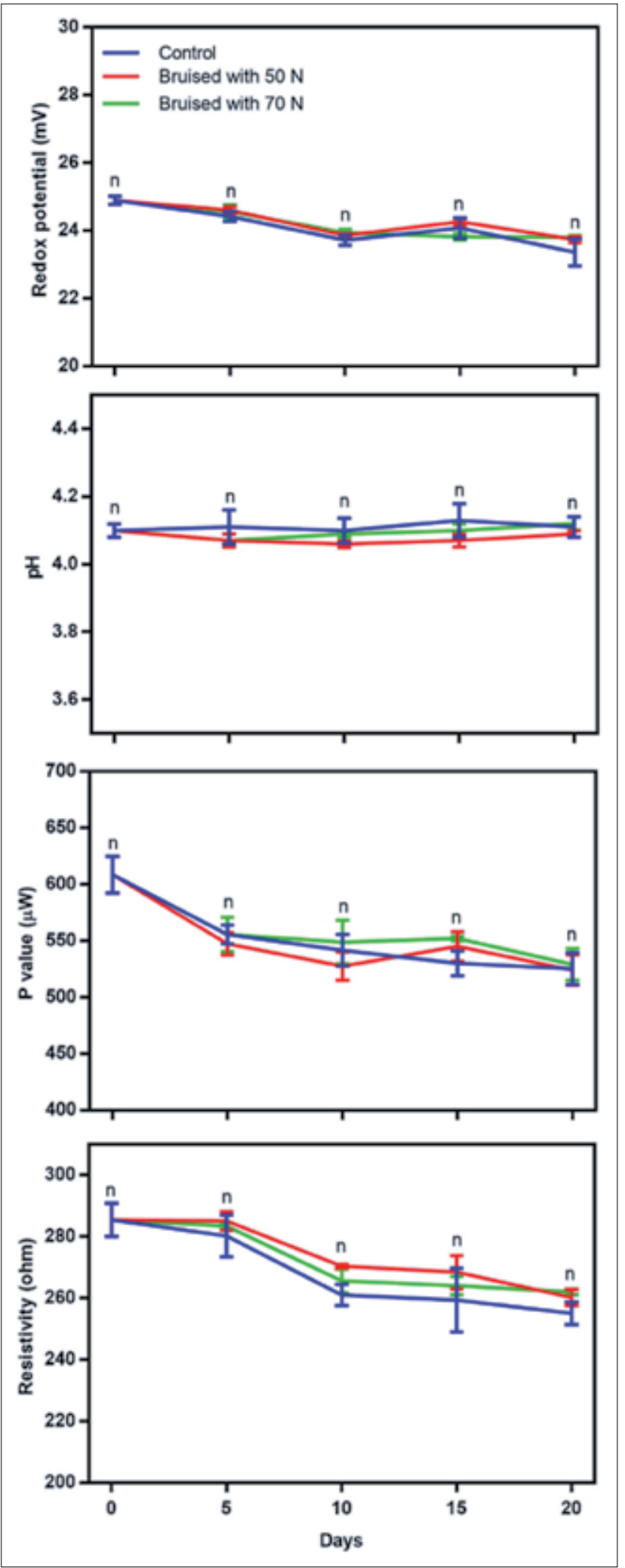

FIGURE 6. Changes in electrochemical parameters (redox potential, $\mathrm{pH}, \mathrm{P}$-value and resistivity) of non-bruised and bruised 'Galaxy' apple fruits stored at $15^{\circ} \mathrm{C}$ for 20 days. Values are the mean \pm S.E. of 10 replicates. Means followed by the same letters on the same day are not significant different by LSD test at $P<0.05$. n: nonsignificant. 


\section{Soluble solids content, titratable acidity and vitamin C}

SSC, TA and vitamin C content for all treatments very slightly decreased in course of the storage, with having no significant differences among treatments (Figure 5). Thus bruising did not modify food value of 'Galaxy' apple fruit as assessed SSC, TA and vitamin C content probably due to the degree of bruising which localized over a very restricted area.

\section{Redox potential, $\mathrm{pH}, \mathrm{P}$-value and resistivity}

Redox potential $(\mathrm{mV})$ and $\mathrm{pH}$ values for 'Galaxy' apples decreased during the course of storage regardless of treatments but the magnitude was so small and therefore it could be neglected (Figure 5). P-value also decreased from approximately 610 to $530(\mu \mathrm{W})$ during the period of storage, and it was unaffected by bruising as well (Figure 6). Similar to $\mathrm{P}$-value, resistivity values (ohm) also decreased over time irrespective of treatments (Figure 6).

According to Bioelectric Vincent method, better product qualities are expected to attain a low redox potential and a low P-value but higher resistivity (Wolf and Rey, 1997). In the present experiment both the initial P-values for all the treatments were lower than the final values, indicating that bioelectric value of the apples increased according to method. On the other hand, resistivity values at the end of the storage for all the treatments were also lower than the initial values, indicating that bioelectric value of the apples decreased according to method. The conflict between P-value and resistivity obstructs a definitive comment for the bioelectric value of 'Galaxy' apples after prolonged storage.

Unlike the present experiment, product quality in connection with bioelectrical properties of 'Golden Delicious' apple cultivar was well presented by Keppel (1998). In his work, 17 different fertilizers were applied to apples and it was found that apples receiving organic-based fertilizers AgroBiosol ${ }^{\circledR}$ and Biosol ${ }^{\circledR}$ had lowest P-value, indicating high quality. Similarly, P-values have been reported lower in organically grown carrots compared to conventionally grown carrots (Walz, 1996; Velimirov, 2004, 2005). Krautgartner (2002) and Velimirov (2004) also presented that organically-fertilized spinach had lower P-values. Furthermore, Velimirov (2004) reported that organically-fertilized spinach had less dry matter loss, claiming a longer shelf life.

\section{Conclusions}

The Bioelectric Vincent method failed to detect minor bruising on 'Galaxy' apples. Instrumental colorimeter, on the other hand, detected the bruising very effectively. Thus still X-ray methods, UV, color and infrared cameras with high speed and resolution which are very expensive are the few effective methods to detect minor bruising in apples yet.

\section{References}

Akay, A., and Kara, Z. (2006). P-Value and some other characteristics of tomato cultivar grown in greenhouse. Pak. J. Biol. Sci. 9(10), 19911994. https://doi.org/10.3923/pjbs.2006.1991.1994.

Ergun, M. (2012). Efficacy and inefficacy of refrigerated storages on some physical, physiochemical and electrochemical properties for organically-grown 'Royal Glory' and 'Redhaven' peaches. J. App. Bot. Food Qual. 85, 79-85.

Ergun, M., and Jezik, K.M. (2011). Measuring electrochemical fruit quality of refrigerated 'Hanita' plum by Bioelectric Vincent Method. Zemdirbyste 98(3), 315-322.
Gajewski, M., Szymczak, P., Elkner, K., Dąbrowska, A., Bret, A., and Danilcenko, H. (2007). Some aspects of nutritive and biological value of carrot cultivars with orange, yellow and purple-colored roots. Veg. Crop. Res. Bull. 67, 149-161.

Hoffmann, M. (1991). Elektrochemische Merkmale zur Differenzierung von Lebensmitteln. In Lebensmittelqualität - ganzheitliche Methoden und Konzepte-alternative Konzepte, A. Meier-Ploeger, and H. Vogtmann, eds. (Deukalion Verlag, Germany), p. S67-86.

Kaçiu, S., Shala-Mayrhofer, V., Mirecki, N., Aliu, A., and Jezik, K. (2010). Influence of environment in electrochemical quality of tomato. Int. J. Hortic. Sci. 16(5), 17-20.

Kappert, R., and Meltsch, B. (2007). Introducing a complementary investigation method concerning fruit and vegetable quality and human health. Acta Hortic. 744, 79-90. https://doi.org/10.17660/ ActaHortic.2007.744.7.

Keppel, H. (1998). Measurability of the biological quality of apples by means of $\mathrm{p}$ value as dependent on different fertilizers. Obstbau Weinbau 35, 259-261.

Knee, M., and Miller, A.R. (2002). Mechanical injury. In Fruit Quality and its Biological Basis, M. Knee, ed. (Sheffield, UK), p. 157-179.

Kok, D., and Bal, E. (2017). Electrochemical properties and biochemical composition of cv.Shiraz winegrape (V.vinifera L.) depending on various dose and application time of foliar microbial fertilizer treatments. Erwerbs-Obstbau, p. 1-6. https://doi.org/10.1007/ s10341-017-0319-9.

Krautgartner, G. (2002). Qualitätsuntersuchungen an Gemüsearten im Rahmen einer dreijährige Fruchtfolge während der Umstellung auf unterschiedliche Produktionssysteme mit Schwerpunkt auf elektrochemische Untersuchungen. (Ph.D. thesis) (Vienna, Austria: the University of Natural Resources and Life Sciences in Vienna), p. 200.

Meltsch, B., Kappert, R., and Jezik, K. (2005). Verbraucherakzeptanz und Qualitätsmerkmale von Verschiedenen Handelsüblichen Säften. Deutsche Gesellschaft für Qualitätssicherung (pfl. Nahrungsmittel) 40, 96-100.

Pang, D.W., Studman, C.J., Banks, N.H., and Baas, P.H. (1996). Rapid assessment of the susceptibility of apples to bruising. J. Agr. Eng. Res. 64, 37-48. https://doi.org/10.1006/jaer.1996.0044.

Pasini, L., Ragni, L., Rombola, A.D., Berardinelli, A., Guarnieri, A., and Marangoni, B. (2004). Influence of the fertilization system on the mechanical damage of apples. Biosyst. Eng. 88, 441-452. https:// doi.org/10.1016/j.biosystemseng.2004.04.014.

Paulauskiene, A., Danilcenko, H., Jariene, E., Gajewski, M., Seroczyńska, A., Szymczak, P., and Korzeniewska, A. (2006). Quality of pumpkin fruits in relation to electrochemical and antioxidative properties. Veg. Crop. Res. Bull. 65, 137-144.

Studman, J. (1997). Factors affecting the bruise susceptibility of fruit. In Plant Biomechanics, Conference Proceedings, J.F.V. Vincent, ed. (Reading, UK: University of Reading), p. 273-282.

Toivonen, P.M.A., Hampson, C., Stan, S., McKenzie, D.L., and Hocking, R. (2007). Factors affecting severity of bruises and degree of apparent bruise recovery in a yellow-skinned apple. Postharv. Biol. Technol. 45, 276-280. https://doi.org/10.1016/j.postharvbio.2007.01.018.

Velimiro, A. (2004). Integrative methods of product quality assessment in connection the p-value-determination ( 3 examples: food preference test, sensory evaluation and self-decomposition test). Hort. Sci. 31, 17-21.

Velimirov, A. (2005). The consistently superior quality of carrots from one organic farm in Austria compared with conventional farms. In Researching and Shaping Sustainable Systems, $15^{\text {th }}$ IFOAM Organic World Congress, U. Köpke, U. Niggli, D. Neuhoff, P. Cornish, W. Lockeretz, and H. Willer, eds. (Adelaide, South Australia), p. 192-195. 
Walz, V. (1996). The p-value as a holistic quality parameter for food experiments with organically and non-organically grown carrots (Daucus carota ssp. sativus cv. 'Bolero'). In New Research in Organic Agriculture, Proceedings of $11^{\text {th }}$ International Scientific IFOAM Conference, N.H. Kristensen, and H. Hoegh-Jensen, eds. (Copenhagen, Denmark), pp. 265-272.

Weissinger, H., Stich, K., Spornberger, A., and Jezik, K. (2008). Influence of harvest progression on fruit quality parameter of earlyripening strawberry types. Deut. Lebensm.-Rundsch. 104, 59-66.

Wolf, G., and Rey, C. (1997). Wie Qualität elektrochemisch zu messen ist. In Vom lebendigen in Lebensmitteln, M. Hoffmann, ed. (Deukalion Verlag, Germany), p. 50-60.

Zeebroeck, M.V., Van Linden, V., Ramon, H., de Baerdemaeker J., Nicolai, B.M., and Tijskens, E. (2007). Impact damage of apples during transport and handling. Postharv. Biol. Technol. 45, 157-167. https://doi.org/10.1016/j.postharvbio.2007.01.015.

Received: Feb. 16, 2017

Accepted: May 19, 2017

Address of author:

Muharrem Ergun

Department of Horticulture, Bingol University, Bingol, Turkey E-mail: muharrem.ergun@yahoo.com

Tel.: ++90 4262160012 , ext. 1137;

Fax: ++904262160029 